\title{
Minimum wage and financially distressed firms: Another one bites the dust ${ }^{\text {ir }}$
}

\author{
F. Alexandre ${ }^{a}$, P. Bação ${ }^{b}$, J. Cerejeira ${ }^{a}, H$. Costa $^{a}$, M. Portela ${ }^{c, *}$ \\ ${ }^{a}$ NIPE/Universidade do Minho, Portugal \\ ${ }^{\mathrm{b}}$ FEUC, Universidade de Coimbra, CeBER, Portugal \\ ${ }^{\mathrm{c}}$ NIPE/Universidade do Minho and IZA Bonn, Portugal
}

\section{A R T I C L E I N F O}

\section{Keywords:}

Minimum wages

Financially distressed firms

Productivity

JEL classification J38

L25

\begin{abstract}
A B S T R A C T
Since late 2014, Portuguese Governments adopted ambitious minimum wage policies. Using linked employeremployee data, we provide an econometric evaluation of the impact of those policies. Our estimates suggest that minimum wage increases reduced employment growth and profitability, in particular for financially distressed firms. We also conclude that minimum wage increases had a positive impact on firms' exit, again amplified for financially distressed firms. According to these results, minimum wage policies may have had a supply side effect by accelerating the exit of low profitability and low productivity firms and, thus, contributing to improve aggregate productivity through a cleansing effect.
\end{abstract}

\section{Introduction}

This paper assesses the impact on firms of minimum wage policies in Portugal, since the end of the Financial Assistance Programme in 2014. The goal of those measures was to reduce poverty and income inequality. The strong increase in the share of workers earning the minimum wage - from $13.2 \%$ in 2014 to $25.7 \%$ in 2017 — raised concerns about the impact of its increase on firms activity and financial condition. Business associations - especially in the traditional sectors, such as apparel and textiles - were vocal about the potential negative consequences of these increases, given that Portugal had been through a severe debt and banking crisis, that left many firms financially vulnerable and constrained in their ability to adjust to the increase in wage costs. After the initial controversy, the discussion on this topic faded away because it occurred in the context of a strong rise in employment and a sharp reduction in unemployment, as the economy rebounded from the crisis. To the best of our knowledge, there is no evaluation of the impact of those minimum wage increases. The first contribution of this paper is to present an evaluation of the impact of those policies on firms' employment, profitability and exit. Our estimates support business associations concerns, suggesting that minimum wage increases reduced employment growth and profits, and accelerated the exit of financially distressed firms. The impact of the COVID-19 pandemic crisis on the financial situation of firms - which led to credit deferrals that amounted to over $20 \%$ of total bank credit (European Banking Authority, 2020) - has revived interest in this issue, given that the minimum wage in Portugal has continued to increase in spite of the recession.

The costs of social policies implemented through minimum wage increases are, at least partially, borne by firms. The share borne by a specific firm depends on several factors. First, the impact on firms' total costs depends on the share of workers affected by the new minimum wage. Second, it will depend on the firms' ability to absorb the wage cost shock by adjusting its profit margin and/or to pass the cost increase to consumers. Finally, the impact of minimum wage policies will depend on firms' flexibility to change their capital-to-labor ratio. If firms are unable to fully offset the impact of the minimum wage increase, their financial condition will worsen. In more extreme cases, namely when firms are financially distressed, the minimum wage increase may lead to the death of the firm. The second contribution of this paper is to propose a new, more complete measure, of the potential relative cost

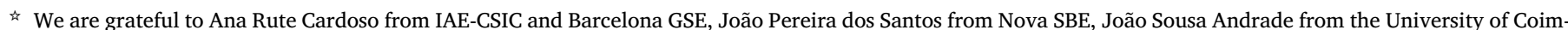

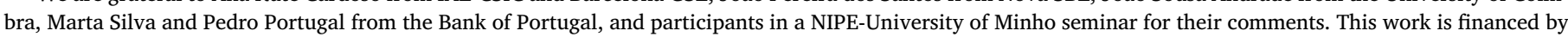

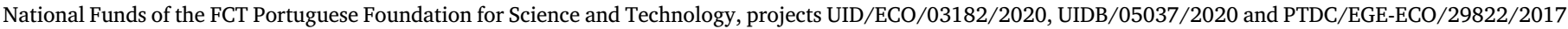

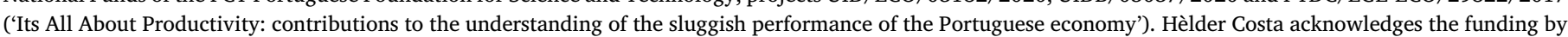
FCT, scholarship 2020.04643.BD.

* Corresponding author.

E-mail address: miguel.portela@eeg.uminho.pt (M. Portela).
} 
increase (PRCI) for firms of minimum wage policies, making use of a very rich firm-level database. In our data, the value of PRCI is higher for the group of financially distressed firms than for the rest of the economy, suggesting that those firms are more vulnerable to minimum wage increases.

While the main dispute in the literature has concerned the impact of minimum wage increases on employment (e.g., contrast the views expressed in Dube (2019), and Neumark and Shirley (2021), a very recent strand of the literature has been focusing on the impact of minimum wage increases on the financial condition of firms. Examples include Draca et al. (2011), for the introduction of a minimum wage in the United Kingdom in 1999; Harasztosi and Lindner (2019) for a large increase in the Hungarian minimum wage in 1997-2004; Chava et al. (2019) for 14 states of the USA, with a focus on the credit score of small firms; and Drucker et al. (2021) for Israel in 2003-2010. Bell and Machin (2018) conclude that low-wage UK firms had significant falls in their stock market value following the announcement of a big change in the minimum wage. All these papers present evidence of a negative impact of minimum wage increases on firms' profitability.

Framed by this line of research, the third contribution of this paper is to show that minimum wage increases are particularly detrimental to financially distressed firms. The relation between firms financial conditions and minimum wage increases is especially relevant in the Portuguese economy because a significant share of the firms are highly indebted, and have very low profitability and liquidity. Therefore, in our econometric analysis we allow for the possibility that the minimum wage increase has a more acute effect on financially distressed firms. Our results warrant this hypothesis. According to the estimates reported in this paper, minimum wage increases lead to lower profits and lower employment growth, with magnified effects for financially distressed firms. These results suggest that policy makers should take into account the financial condition of firms when deciding minimum wage increases.

The empirical literature on the impact of minimum wage increases on firm exit is also relatively recent. Draca et al. (2011) presents industry-level evidence of the impact of the introduction of a minimum wage in the UK and concludes that the probability of exit increased 1.5 percentage points. Mayneris et al. (2018) detects evidence of a 'cleansing' effect of the large increases in the minimum wage in 2004 in China, i.e., less productive firms were more likely to be exposed to the minimum wage increase and were also more likely to exit. Chava et al. (2019) relate increases in the minimum wage to lower credit scores and consequent higher exit rates of small businesses in the USA. Aaronson et al. (2018) and Luca and Luca (2019) focus on restaurants; both conclude that minimum wage rises increase the probability of exit.

Adding to this discussion, the fourth contribution of this paper is to show that minimum wage increases acted as a potential accelerator of the exit of financially distressed firms, also known as zombie firms. This conclusion indicates that minimum wage policies may have compensated for some inefficiency of the insolvency framework. Therefore, our results suggest that minimum wage increases produce a cleansing effect, which may foster a more efficient resource allocation and productivity growth. In the context of the COVID-19 pandemic crisis, the issue of zombie firms has re-emerged, given the severity of the crisis and the Governments' intervention to support firms (European Central Bank, 2021). The ECB's 2021 Financial Stability Review highlights the risks of inefficient insolvency frameworks, which might contribute to the prevalence of zombie firms and, thus, hamper productivity growth. In this context, the evaluation of the impact of minimum wage increases on firm exit, namely of zombie firms, becomes even more relevant.

The remainder of this paper is structured as follows. Section 2 describes the main facts concerning the evolution and incidence of minimum wage and financially distressed firms in the Portuguese economy. Section 3 presents the dataset, empirical strategy and results. Section 4 concludes.

\section{Minimum wage and financially distressed firms in the Portuguese economy}

Starting in late 2014, Portuguese Governments adopted an ambitious policy of minimum wage increases. This policy put an end to a long period when the nominal minimum wage was frozen. Between 2008 and 2013, the Portuguese economy went through a severe crisis: GDP decreased by $8 \%$; employment decreased $13 \%$ and unemployment increased from 7.7\% to 16.4\%. Between May 2011 and May 2014, following the bailout by the International Monetary Fund, the European Commission and the European Central Bank, also known as troika, Portugal implemented an Economic and Financial Assistance Program.

The Portuguese crisis was both a debt and a banking crisis. According to data from the Bank of Portugal, total debt of non-financial firms, relative to GDP, reached a maximum of $152 \%$ in 2012 , one of the highest in the world. Besides being highly leveraged, there was a large fraction of unprofitable firms. In 2013, 34\% of the firms had a negative EBITDA (Earnings Before Interest, Taxes, Depreciations and Amortizations) and the average EBITDA to Operating Revenue ratio across all firms in the economy was $-15.5 \%$ (data from SCIE, INE; see Section 3.1 for further details on the data used in this paper). A high share of firms, accounting for a high share of employment, value added and debt, were financially distressed - see Gouveia et al. (2018).

In our analysis, following the OECD approach - see, for example, McGowan et al. (2017) and Gouveia et al. (2018) — we define as financially distressed the firms that report an Interest Coverage Ratio (ICR) given by the ratio of EBITDA to interest expenses - lower than one over three consecutive years. EBITDA measures the financial performance of the firm and interest expenses gives the costs due to borrowing. As startups are not expected to be profitable, in our definition of financially distressed firms we only consider firms that already existed in 2010 .

Alternative definitions of financially distressed firms - sometimes also referred to as zombie firms - have been used in the literature. Caballero et al. (2008), in a seminal contribution, define zombie firms as those receiving subsidised bank credit. A firm is assumed to be receiving subsidised bank credit when the implicit interest rate on its debt is less than the prime interest rate. A similar approach is used in Schivardi et al. (2021). Schivardi et al. (2021) label a firm as financially distressed when its return on assets is lower than the cost of capital for the safest borrowers, and the ratio of financial debt to assets is higher than $40 \%$. Both these approaches require more detailed information concerning the financial markets in which the firms fund themselves than the OECD approach. In face of the data available to us, we will not pursue these approaches. An alternative that is closer to the OECD approach is that of Storz et al. (2017), who classify a firm as zombie if it shows negative return on assets for two consecutive years, negative net investment, and a ratio of EBITDA to total financial debt lower than $5 \%$.

In Fig. 1, we show the evolution of the share of financially distressed firms in Portugal, in the period 2012-2017, according to both our preferred measure - denoted by ' $I C R<1$ ' - and the measure proposed by Storz et al. (2017) — denoted by 'ROA'. We also show the evolution of the share of financially distressed firms according to a less stringent version of the OECD criterion, requiring that the ICR be lower than 1.5 rather than 1 (' $I C R<1.5$ '). This brings into the fold firms that are not far above the OEDC threshold. We use these two alternative indicators of financial distress in our empirical analysis to perform robustness checks. In both cases, the size of the sample of financially distressed firms is larger than in our main estimations. In fact, using the OECD approach, the share of financially distressed firms reached a peak of 5.8\% in 2014 . In 2013 , financially distressed firms represented $5 \%$ of total employment, $1.3 \%$ of total gross value added, $11.5 \%$ of total debt and $14 \%$ of total interest expenses. When we use 1.5 instead of 1 as the cutoff, the share of financially distressed firms increases by more than 1 percentage point (p.p.) in 2012-15, and by a slightly narrower margin in 2016-17. The peak is still in 2013 , with a share of $7.2 \%$. According to the measure 


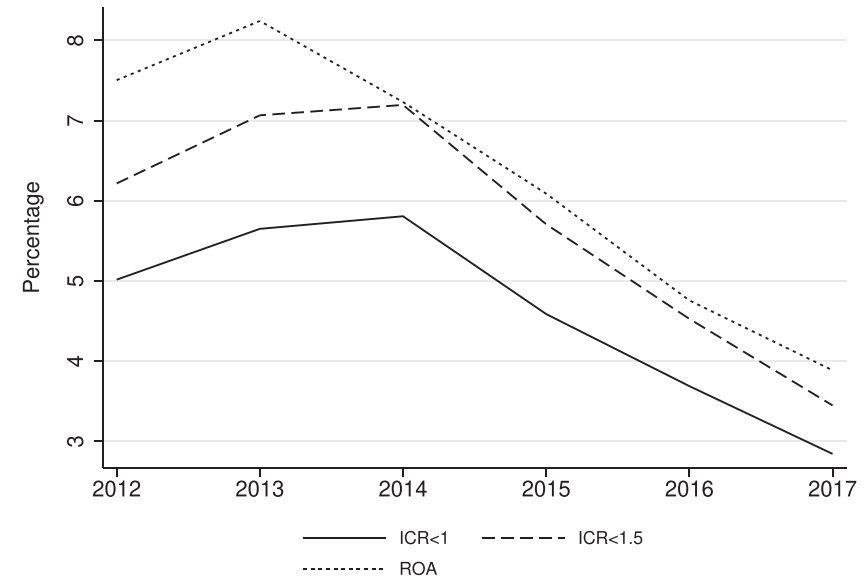

Fig. 1. Share of financially distressed firms Source: Authors' computations using data from SCIE.

used by Storz et al. (2017), the share of financially distressed firms in the Portuguese economy is significantly larger and the peak is also reached earlier: the peak is in 2013 with a share of $8.2 \%$. Those firms accounted for $6.5 \%$ of total employment, $2.9 \%$ of total gross value added, $10.5 \%$ of total debt and $11.5 \%$ of total interest expenses.

The fragile condition of financially distressed firms raised concerns about the effects of minimum wage policies. Minimum wage increases may induce a further deterioration of the financial condition of those firms, which may lead them to reduce employment and even to close down. Business leaders publicly expressed their concerns on the effects of wage cost increases, namely in sectors where there is a high minimum wage incidence and labor costs weigh heavily in total costs.

The minimum wage in Portugal is set for a month of full-time work. The full-time weekly hours, which by law cannot exceed 40 hours, are set in the collective bargaining agreement. Between 2014 and 2017, the minimum wage increased $14.8 \%$. In October 2014 , the minimum wage increased from 485 to 505 euros per month, a 4\% change. Notwithstanding being a small increase, the percentage of workers receiving minimum wage jumped from $13.2 \%$ to $19.6 \% .^{1}{ }^{1}$ In 2016 , the Government announced that the minimum wage should reach 600 euros in 2019. In 2016 it increased to 530 euros; in 2017 to 557; in 2018 to 580; and in 2019 to 600 euros. During this period, the share of workers receiving the minimum wage reached a maximum of $25.7 \%$ in 2017 . However, the debate about the negative impact of minimum wage policies abated because they coincided with the recovery of the Portuguese economy. Between 2013 and 2018, real GDP increased by 11\% and the unemployment rate decreased from $16.2 \%$ to $7 \%$. This expansion resulted in a $10 \%$ increase in employment, corresponding to 437 thousand jobs for a description of the Portuguese crisis and recovery see, for example, Alexandre et al., 2019 and Blanchard and Portugal (2017).

The costs of minimum wage policies aimed at reducing income inequalities and poverty are, at least partially, borne by firms. However, firms are affected asymmetrically by minimum wage increases. In the short run, the impact on firms' total costs depends on their ability to pass the wage cost increase to consumers, and on the share of workers earning the minimum wage. Since 2016, the share of workers affected by minimum wage policies surpassed $30 \%$ in several industries. For example, in 'Manufacturing' it reached a maximum of $31.6 \%$ in 2016; in 'Construction' it reached $32 \%$ in 2017; in 'Accommodation and food service activities' the share was always above $30 \%$, reaching a maximum of $42.4 \%$ in 2017 .

\footnotetext{
1 The numbers mentioned in this part of the text come from a report on the minimum wage in Portugal published by the Portuguese Ministry of Labor-see Ministério do Trabalho, Solidariedade e Segurança Social, 2019.
}

In this paper, we measure the impact of the minimum wage increase in total costs through a novel measure, which we call the 'potential relative cost increase', henceforth PRCI. The PRCI measures the potential impact of the minimum wage increase on firms' costs. The PRCI builds on other measures in the minimum wage literature. Card and Krueger (1994), in a study of the impact of minimum wage increases on fast-food restaurants, use a 'gap' variable defined as the proportional increase in the starting wage necessary to raise it to the new minimum wage. In Machin et al. (2003) and Draca et al. (2011), the intensity of the treatment is given by the relative change in wage costs needed to comply with the new minimum wage. Harasztosi and Lindner (2019) and Drucker et al. (2021) employ a simpler measure to evaluate the impact of changes in the minimum wage: the fraction of workers who earn below the new minimum wage. Caliendo et al. (2018) evaluate the impact on employment of the introduction of a national minimum wage in Germany in 2015 by exploring the variation in regional treatment intensity by means of two indicators: the share of affected eligible employees per region and the Kaitz index that gives the relation of the minimum wage to the regional mean wage.

Those studies need to resort to approximate measures of exposure to minimum wage hikes because they lack detailed information about the cost structure within firms. In our case, we have this information. Thus we could compute the firm's average wage and compare it to the minimum wage, or compute the fraction of workers earning below the minimum wage. However, we believe that the PRCI is a more complete measure of the exposure of firms to the minimum wage. One reason for this is the fact that the same minimum wage hike should affect laborintensive firms more than capital-intensive firms. The PRCI allows for this difference by taking into account how much the wage increase matters for the firm's total costs.

Thus, in our analysis, the intensity of the treatment of minimum wage policies is measured through the PRCI as defined in Eq. (1):

PRCI $_{i t}=\frac{\text { Potential wage bill }_{i, t+1}-{\text { Current } \text { wage bill }_{i t}}_{\text {Total costs }}}{\text { it }} \times 100$

This equation tells that the 'potential relative cost increase' associated with a minimum wage rise is the relative change in total costs that the firm would face in year $t$ if the firm had to pay in year $t$ the year $t+1$ minimum wage, while maintaining the same productive structure, namely, not adjusting the composition, nor the size, of its labor force in view of the minimum wage increase. By computing the 'potential relative cost increase' we take into consideration the fact that the importance of labor costs varies across industries and firms.

Note that the PRCI is zero if the minimum wage does not change, and that it is an increasing function of the change in the minimum wage. Furthermore, in our empirical model (see Section 3.2) PRCI is the only variable that depends directly on the variation of the minimum wage. In this sense, the PRCI is an indicator of the exposure of each firm to minimum wage hikes, and its coefficient will reflect the impact of the minimum wage on the dependent variable in each model. As in Harasztosi and Lindner (2019), our identification assumption is that, conditional on the controls, the path followed by those firms where the minimum wage hike matters less may be viewed as a counterfactual for the firms where the minimum wage hike is more important. Harasztosi and Lindner (2019) provide one major argument in favour of this assumption: a minimum wage hike represents a small additional cost for the economy as a whole. Therefore, the associated general equilibrium effects are probably negligible. In addition, the general equilibrium effects would probably be at least partly absorbed by exchange rate fluctuations. Note also that the PRCI does not measure any impact of the minimum wage hike that might occur through a spillover across the firm's wage distribution.

To control for absenteeism and part time jobs, in the computation of the PRCI we use the hourly minimum wage. In 2014, the minimum wage increased in October, affecting only the last quarter of the year. The next increase occurred in January 2016. Consequently, we split the 


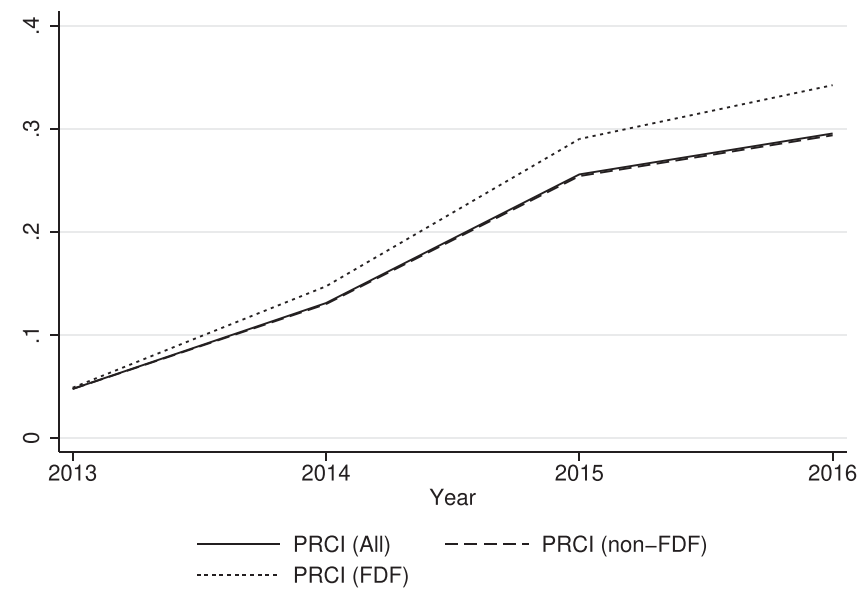

Fig. 2. Average PRCI Source: Authors' computations using data from QP.

2014 increase (from 485 euro to 505 euro) between 2014 (one quarter of the increase) and 2015 (the other three quarters). This amounts to assuming that the minimum wage rose from 485 to 490 in 2014, and from 490 to 505 in 2015.

Fig. 2 shows the evolution of the average PRCI for the period 20132016. We present data for all firms, 'PRCI (All)', for non-financially distressed firms, 'PRCI (non-FDF)', and for financially distressed firms, 'PRCI (FDF)'.

The average value of the PRCI increased significantly (more than sixfold) over time. The increase in the average PRCI reflects the fact that minimum wage rises resulted in a higher share of workers earning the minimum wage, implying cumulative effects in the value of the PRCI. We should also stress the difference between financially distressed firms and non-financially distressed firms. In 2013, the average value of the PRCI was similar for both groups of firms. However, in the following years, the PRCI for financially distressed firms show a faster increase, raising from 0.05 to 0.34 in 2016 (a 604\% increase against 519\% in the case of non-financially distressed firms). The evolution of the PRCI suggests that minimum wage increases might have a stronger impact in financially distressed firms, simply because they are more exposed to the minimum wage. However, in this paper, we also test the hypothesis that financially distressed firms are more vulnerable to minimum wage increases in terms of profitability and employment growth, in the sense that the impact of a minimum wage increase is more damaging for a financially distressed firm than for an otherwise identical firm that is not financially distressed. Likewise, we test the hypothesis that minimum wage increases have a stronger impact on the exit of financially distressed firms.

Previous studies on the impact of minimum wage policies in the Portuguese economy focused on the effects on employment. The results of those studies were ambiguous. Pereira (2003) analyses the impact of the 1987 minimum wage increase on teenagers' employment and concludes that it reduced the employment of 18 and 19 years old and that it increased employment of 20-25 years old. Portugal and Cardoso (2006) also studied the impact of the 1987 minimum wage increase. They find that it lowered the proportion of teenagers hired by firms, but also lowered the proportion of teenagers in job separations. Portugal and Cardoso (2006) conclude that the net impact on teenager employment was positive. Another study on the effect of minimum wage increases in Portugal, Centeno et al. (2014), focused on the period 20022010. This study estimated that a 1 p.p. increase in the minimum wage lowered employment of minimum-wage earners by 1.1 p.p. However, the impact is stronger for young workers and for workers in manufacturing.

The discussion of the impact of minimum wage policies in the Portuguese economy has left out its potential impact on the financial con- dition of firms. Nevertheless, as mentioned above, there is evidence for the UK (Draca et al., 2011), for the US (Chava et al., 2019) and for Israel (Drucker et al., 2021) that the minimum wage is a determinant of firms' profitability. Given the financial fragility of Portuguese firms and the significant and consecutive increases of the minimum wage in Portugal since 2014, this is an important issue that we also address in this paper, in addition to providing further evidence concerning the impacts on employment and exit.

\section{Empirical analysis}

\subsection{Data}

The data used in our econometric analysis comes from two main sources. The first is the Integrated Business Accounts System (SCIE, 'Sistema de Contas Integradas das Empresas', INE, Statistics Portugal, 2018b) from Statistics Portugal's Registry of Statistical Units. The SCIE database contains firm-level administrative data regarding the balance sheet and other yearly accounting information for the population of firms in the private sector, from 2006 until 2017. In 2017, the SCIE database had 394,967 firms. From SCIE we collected data for EBITDA, operating and total revenue, interest expenditure, value added, labor costs, total costs, leverage, debt, total assets and exports - see Table 1. We consider that a firm exits the economy, Exit, when its information ceases to appear in the SCIE database. It is possible that firms do not report information in SCIE and still exist. This is the case, for example, when they do not have significant economic activity in a given year or when they report the information after the legal due date. The number of cases is expected to be very small. Another possibility is when the economic activity is reclassified from the non-financial to financial sector. As we do not have data on financial firms we cannot confirm this change. However, this is also expected to occur very rarely.

The other database used in our analysis is a linked employeremployee dataset, the Personnel Records database (QP, 'Quadros de Pessoal', INE, Statistics Portugal, 2018a) collected by the Portuguese Ministry of Labor, Solidarity and Social Security (MTSSS) through a mandatory annual survey. The QP database provides data on all workers in all firms in Portugal (excluding the public sector) with at least one wage earner, besides other firm-level information. In 2017, the QP database had 290,409 firms and 2,973,246 workers. From the QP database we use worker-level information on the number of employees, wage bill, hours of work and type of contract (part-time and fixed-term) - again see Table 1. The SCIE database is linked, through an anonymized firm identifier, to the QP data, resulting in a very rich database.

Table 2 shows aggregate statistics for the period of our empirical analysis (about 370 thousand observations corresponding to almost 100 thousand firms). Note that we only use data concerning mainland Portugal. Firms from the archipelagos of Madeira and Azores are excluded from our analysis because these regions have specific minimum wage rules.

\subsection{Econometric strategy}

This paper aims at studying the impact on firms of minimum wage policies. We focus our analysis on profitability, employment growth and exit. In our analysis, we also aim at evaluating whether financially distressed firms are more vulnerable to minimum wage increases.

To test our hypothesis we estimate the following model:

$\Delta$ Profit $_{i, t+1}=\gamma_{1} P R C I_{i t}+\gamma_{2} F D F_{i t}+\gamma_{3} P R C I_{i t} F D F_{i t}+\gamma_{4}^{\prime} X_{i t}+\eta_{i}+\varepsilon_{i t}$

The dependent variable in Eq. (2), Prof $i t_{i t+1}$, stands for firm $i$ 's profitability and is given by the change in the EBITDA to Operating Revenue ratio from period $t$ to period $t+1$. In the case that the firm exits the market in period $t+1$, we do not know what would have happened to the 
Table 1

Variable description and sources.

\begin{tabular}{|c|c|c|}
\hline Variable & Description & Source \\
\hline Potential relative cost increase & PRCI $=\frac{\text { Potencial wage bill } t_{t+1}-\text { Current wage bill }_{t}}{\text { Total cost } s_{t}} \times 100$ & QP and SCIE \\
\hline Profitability & Profit $=\frac{E B I T D A}{\text { Operating revenue }} \times 100$, winsorized at percentiles 1 and 99 & SCIE \\
\hline Interest coverage ratio & $\mathrm{ICR}=\frac{E B I T D A}{\text { Interest expenses }}$ & SCIE \\
\hline Employment growth & Employment $=\frac{\text { Number of employee } s_{t+1}-\text { Number of workers }_{t}}{\text { Number of employees } s_{t}} \times 100$ & QP \\
\hline Productivity & Productivity $=\frac{\text { Value added }}{\text { Total hours worked }} \times 1$ (Euro, thousand $)$ & QP and SCIE \\
\hline Part-time workers & Part-time $=\frac{\text { Workers with a part-time contract }}{\text { Number of workers }} \times 100$ & QP \\
\hline Fixed-term workers & Fixed-term $=\frac{\text { Workers with a fixed-term contract }}{\text { Number of workers }} \times 100$ & QP \\
\hline Overtime labor & Overtime $=\frac{\text { Overtime hours }}{\text { Total hours worked }} \times 100$ & QP \\
\hline Relative labor costs & LaborCosts $=\frac{\text { Labor costs }}{\text { Total costs }} \times 100$ & SCIE \\
\hline Exports weight & Exports $=\frac{\text { Exports }}{\text { Total revenue }} \times 100$ & SCIE \\
\hline Leverage ratio & Leverage $=\frac{\text { Total liabilities }}{\text { Total assets }} \times 100$ & SCIE \\
\hline Short-term debt & DebtST $=\frac{\text { Short-term loans }}{\text { Total assets }} \times 100$ & SCIE \\
\hline Long-term debt & DebtLT $=\frac{\text { Long-term loans }}{\text { Total assets }} \times 100$ & SCIE \\
\hline Financially distressed firms & $\mathrm{FDF}=\mathrm{ICR} \geq 1$ for 3 consecutive years for firms that already existed in 2010 & SCIE \\
\hline Exit & Exit $=1$ if the firm exited from the database; 0 otherwise & SCIE \\
\hline
\end{tabular}

Notes: SCIE stands for "Sistema de Contas Integradas das Empresas" and QP for "Quadros de Pessoal". Total costs includes costs with employees, goods, external services, interest expenses and losses by firm/year. EBITDA stands for earnings before interest, taxes, depreciation and amortization. Potential and current wage bill are computed using data from QP. The variable total hours worked is from QP, while value added is available in SCIE.

Table 2

Summary statistics (2013-2016).

\begin{tabular}{|c|c|c|c|c|}
\hline & Mean & SD & Min. & Max. \\
\hline PRCI & 0.18 & 0.43 & 0.00 & 130.37 \\
\hline FDF & 0.05 & 0.22 & 0 & 1 \\
\hline Profit & -9.87 & 48.91 & -227.89 & 230.61 \\
\hline Exit & 0.04 & 0.20 & 0 & 1 \\
\hline Productivity & 17.46 & 450.25 & -4594.66 & 248074.48 \\
\hline Part-time & 5.65 & 16.28 & 0.00 & 100.00 \\
\hline Fixed-term & 22.45 & 29.26 & 0.00 & 100.00 \\
\hline Exports & 4.15 & 15.45 & 0.00 & 100.00 \\
\hline Leverage & 107.01 & 1699.23 & -277.41 & 810637.50 \\
\hline DebtST & 0.08 & 1.95 & 0 & 713.66 \\
\hline DebtLT & 0.27 & 9.23 & 0 & 5046.94 \\
\hline Number of workers & 18.59 & 164.10 & 1 & 24682 \\
\hline
\end{tabular}

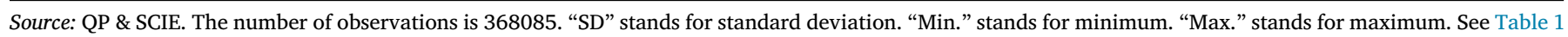
for further information.

profit of the firm. We assume that the performance would have been poor and, therefore, we set the change in Profit equal to the minimum value observed in the series. As this may overestimate the fall in Profit, as a robustness check we will also estimate the model omitting these observations.

In Eq. (2), $P R C I_{i t}$ is the exposure of firm $i$ in year $t$ to an increase of the minimum wage during year $t+1$ (computed as detailed in the previous section). $F D F_{i, t}$ is a dummy variable that equals 1 if firm $i$ was classified as financially distressed in year $t$ and equals 0 otherwise. $X_{i t}$ is a vector of control variables, which includes the variables productivity, part-time workers, fixed-term workers, overtime labor, relative labor costs, exports weight, leverage ratio, short-term debt, long-term debt all defined in Table 1 - as well as the number of workers and its square. $\eta_{i}$ represents firm $i$ 's unobserved heterogeneity. The key parameters of interest are those associated with our treatment variable, $P R C I_{i t}$, i.e. $\gamma_{1}$ and $\gamma_{3}$. If $\gamma_{1}<0$, an increase in the minimum wage will be detrimental to profitability. This impact will be larger for financially distressed firms if $\gamma_{3}<0$.
One possible reaction of firms to a minimum wage increase, namely if they cannot pass the cost to consumers, is to reduce their demand for labor. For firms that are more dependent on low-wage labor, the increase in costs may trigger the closing down of the firm and the destruction of all jobs. Therefore, to assess the impact of minimum wage increases on employment, we estimate a model with the same specification as in Eq. (2), except for the dependent variable, which becomes the change in log-employment from $t$ to $t+1$. For firms that exited in period $t+1$ we recorded a variation in employment equal to minus 100 percent. The parameters of interest $\left(\gamma_{1}\right.$ and $\left.\gamma_{3}\right)$ and their interpretation are the same as in the model for profitability.

To evaluate the impact of minimum wage increases on firm exit, we begin by estimating a logit model that accounts for firms' unobserved heterogeneity and in which the dependent variable is the probability that firm $i$ will close down in period $t+1$. This probability is assumed to be a function of a set of explanatory variables - collected in vector $Z_{i t}$ - that include PRCI, FDF, their interaction, control variables and 
an individual dummy:

$P\left(E_{i, t+1}=1 \mid Z_{i t}\right)=\lambda\left(\theta_{i t}\right)=\frac{\exp \left(\theta_{i t}\right)}{1+\exp \left(\theta_{i t}\right)}$

$\theta_{i t}=\beta_{1} P R C I_{i t}+\beta_{2} F D F_{i t}+\beta_{3} P R C I_{i t} F D F_{i t}+\beta_{4}^{\prime} X_{i t}+\eta_{i}$

In Eq. (3), $E_{i, t+1}$ (variable 'Exit' in Table 2) is a dummy variable that equals 1 if firm $i$ exited during year $t+1$ and equals 0 otherwise. The other variables are the same as in Eq. (2).

Given the focus of the paper, the main parameters of interest are $\beta_{1}$ and $\beta_{3}$, with $\beta_{2}$ playing a lesser role. The parameter $\beta_{1}$ is the effect on the argument of the exit probability function, $\theta_{i t}$, of increasing wage costs (as a result of raising the minimum wage) in an amount equal to one per cent of total costs, all else equal. Since we use a logit model (Eq. (3)), the impact of this increase for the probability of exit of the firm varies with the value of the other variables in the model. The parameter $\beta_{2}$ is the difference in the value of $\theta_{i t}$ between a financially distressed firm that pays at least the new minimum wage to all workers $\left(P R C I_{i t}=0\right)$ and a non-financially distressed firm with the same characteristics. If firms pay some workers below the new minimum wage $\left(P R C I_{i t}>0\right)$, the difference in $\theta_{i t}$ for a financially distressed firm relative to a non-financially distressed firm with similar characteristics is $\beta_{2}+\beta_{3} P R C I_{i t}$. We interpret $\beta_{1}>0$ as signifying that the minimum wage increase has an adverse impact on the survival of firms that pay the minimum wage to some of its workers. If $\beta_{3}>0$ then the impact of a minimum wage increase is magnified in the case of financially distressed firms. If the increase in the minimum wage raises firms' probability of exit $\left(\beta_{1}>0\right.$ or $\left.\beta_{3}>0\right)$, then it will in effect be accelerating their exit. When $\beta_{3}>0$, the minimum wage increase may have a 'cleansing' effect, in the sense that it may contribute to driving out underperformers faster, as Mayneris et al. (2018) suggest was the case for firms in China.

The above logit model is appealing because it restricts the outcome to a number between zero and one, i.e. interpretable as a probability. However, that comes at a cost in terms of observations: the estimation of the conditional logit model uses only the set of firms that change status in the sample, i.e. the firms that did exit the market in the period 2014-2017. Consequently, a significant positive coefficient for PRCI will suggest that firms that exited did so in years when PRCI was high. It does not necessarily follow that, in the full set of firms (i.e. including those that did not exit), firms with a high PRCI exited more often than firms with a low PRCI, i.e. that minimum wage hikes killed firms. To put this sort of conclusion on firmer ground, we should estimate a model with the full set of firms.

An alternative approach is to use the linear probability model with fixed effects, which can be estimated using the data on all firms. This model may be written as:

$E_{i, t+1}=\tilde{\beta}_{1} P R C I_{i t}+\tilde{\beta}_{2} F D F_{i t}+\tilde{\beta}_{3} P R C I_{i t} F D F_{i t}+\tilde{\beta}_{4}^{\prime} X_{i t}+\tilde{\eta}_{i}+\tilde{\varepsilon}_{i t}$

The interpretation of the sign of the coefficients is the same as in the logit model. However, in the linear probability model the impact of a unit change in one regressor on the probability of exit is constant and equal to that regressor's coefficient. Differently, in the logit model the impact depends on the values taken by the other variables, i.e. the impact depends on the position on the curve. The results reported in the next subsection must be read accordingly.

Models akin to Eq. (5) are common in the literature. As in the case of Eq. (2), the main variation is in the definition of the treatment variable. In Mayneris et al. (2018) the treatment variables are dummy variables that identify firms with different degrees of exposure to the minimum wage. Although it distinguishes several categories of exposure to the minimum wage, this approach is essentially the same as the approach used by Draca et al. (2011), who consider low-wage firms to be the treated group. This dummy-variable approach is in contrast with, e.g., Aaronson et al. (2018). In Aaronson et al. (2018) - as in Luca and Luca (2019) - the treatment variable is the level of the minimum wage in each US state (where the restaurants that constitute their sample are located). Chava et al. (2019) interact the change in the US federal minimum wage with a dummy for those states where the minimum wage is binding and another dummy for firms that suffered a rating downgrade from 80 to 79 points. All these papers find that minimum wage rises lead to a higher probability of exit for the firms in the treated group.

The dummy variables provide only a very coarse measure of the treatment. In the papers that employ that approach, robustness checks that use an alternative measure of the treatment are common. Given that we use a continuous measure of the treatment intensity instead of a dummy (or a set of dummies), our approach appears to be closer to that of Aaronson et al. (2018), Luca and Luca (2019) and Chava et al. (2019). Nevertheless, there are important differences. First, as emphasized in Section 2, our treatment measure is probably a more precise indicator of the impact of the minimum wage hike, for it measures the importance of each minimum wage hike in the context of the firm's total costs. Second, we look at the full set of firms in continental Portugal (subject to the conditions detailed in Section 3.1), whereas those papers analyze a special population of firms (restaurants or businesses with a Dun\&Bradstreet credit score). Finally, while in continental Portugal there is only one minimum wage, those papers exploit the variation of the minimum wage across the states of the USA to achieve identification.

Note that the models described above focus on the 'short-run' (from one year to the next) impact of variations in the minimum wage, and are silent about long-term effects. In addition, these models concern the impact on existing firms, not on potential entrants. These two features suggest that the actual impact of minimum wage changes may be larger than estimated by these models.

\subsection{Results}

The results from estimating models (2) (with the change in the EBITDA ratio and the change in employment as dependent variables), (3)-(5) (using both the sample of firms that exited during 2014-2017 and the full sample) are reported in Table 3. We report two sets of results, with and without control variables. The estimates are virtually unchanged by the inclusion of controls. This invariance to the inclusion of controls - which is also a feature of Harasztosi and Lindner (2019) means that the control variables are essentially orthogonal to the other variables, namely to PRCI. Panel A in Table 3 presents the estimates of a simpler version of those models, omitting FDF and the interaction from the list of explanatory variables. Again, the coefficient on PRCI - as well as its statistical significance - is hardly affected by this omission.

In columns (1) and (2) of Table 3 (Panel B) we report the estimates of coefficients $\gamma_{1}$ (coefficient on the PRCI), $\gamma_{2}$ (coefficient on the dummy variable for financial distress) and $\gamma_{3}$ (coefficient on the interaction of the two variables) of Eq. (2). The estimates of $\gamma_{1}$ and $\gamma_{3}$ are negative and statistically significant at the $1 \%$ significance level. In other words, the results indicate that minimum wage increases have a negative impact on profitability and that the effect is larger for financially distressed firms. In fact, since the estimated $\gamma_{3}(-16)$ is almost the double of $\gamma_{1}$ $(-9)$, the effect of the minimum wage on profitability is almost three times more negative for financially distressed firms. Nevertheless, note that the estimated $\gamma_{2}$ is positive (15.0). This is related to the fact that those financially distressed firms that survive, improve their EBITDA ratio more than non- financially distressed firms. Not doing so would probably have forced those financially distressed firms to exit.

To understand the meaning of the estimates of $\gamma_{1}$ and $\gamma_{3}$, note that the average of the variable that measures treatment $\left(P R C I_{i t}\right)$ is around 0.05 for both financially distressed and non-financially distressed firms in 2013-recall Fig. 2. Multiply this average by $\gamma_{1}$ and obtain -0.5. Therefore the model implies that, on average, the minimum wage increase in 2014 reduced the EBITDA ratio of a non-financially distressed firm by 0.5 p.p. Next add to -0.5 the product of $\gamma_{3}$ and 0.05 , obtaining -1.2 . Now the conclusion is that, on average, the EBITDA ratio of a financially distressed firm fell 1.2 p.p. as a consequence of the minimum wage increase in 2014. Proceeding in the same way, the average esti- 
Table 3

Profitability, employment and exit.

\begin{tabular}{|c|c|c|c|c|c|c|c|c|c|c|}
\hline & \multicolumn{2}{|l|}{ Profit } & \multicolumn{2}{|c|}{ Employment } & \multicolumn{2}{|c|}{ Exit (Logit) } & \multicolumn{2}{|c|}{ Exit (LPM - A) } & \multicolumn{2}{|c|}{ Exit (LPM - B) } \\
\hline & (1) & (2) & (3) & (4) & (5) & (6) & (7) & (8) & (9) & (10) \\
\hline & \multicolumn{10}{|c|}{ Panel A: Baseline } \\
\hline \multirow[t]{3}{*}{ PRCI } & $-9.8842^{* * *}$ & $-9.9816^{* * * *}$ & $-3.9870^{* * * *}$ & $-5.5859^{* * * *}$ & $4.2621^{* * *}$ & $4.2169^{* * *}$ & $0.5652^{* * * *}$ & $0.5631^{* * * *}$ & $0.0420^{* * * *}$ & $0.0421^{* * * *}$ \\
\hline & (3.197) & (3.179) & $(1.458)$ & $(2.000)$ & $(0.203)$ & $(0.193)$ & $(0.044)$ & $(0.043)$ & $(0.014)$ & $(0.014)$ \\
\hline & \multicolumn{10}{|c|}{ Panel B: Full specification } \\
\hline \multirow[t]{2}{*}{ PRCI } & $-9.3802^{* * *}$ & $-9.4769^{* * *}$ & $-3.7410^{* * * *}$ & $-5.3030^{* * * *}$ & $4.2181^{\text {*** }}$ & $4.1676^{* * *}$ & $0.5513^{* * *}$ & $0.5489^{* * * *}$ & $0.0400^{* * *}$ & $0.0400^{* * * *}$ \\
\hline & $(3.093)$ & (3.079) & $(1.408)$ & $(1.950)$ & $(0.254)$ & $(0.222)$ & $(0.045)$ & $(0.045)$ & $(0.013)$ & $(0.013)$ \\
\hline \multirow[t]{2}{*}{ FDF } & $15.0175^{* * * *}$ & $14.9387^{* * * *}$ & $-2.0298^{\text {***** }}$ & $-2.1600^{* * * *}$ & $0.2577^{* * * *}$ & $0.2783^{* * *}$ & $0.0590^{* * * *}$ & $0.0642^{* * *}$ & 0.0024 & 0.0027 \\
\hline & $(0.987)$ & $(0.988)$ & $(0.685)$ & $(0.721)$ & $(0.070)$ & $(0.073)$ & $(0.022)$ & $(0.022)$ & $(0.004)$ & $(0.004)$ \\
\hline \multirow[t]{2}{*}{ PRCI $\times$ FDF } & $-16.2153^{* * * *}$ & $-16.3066^{* * *}$ & $-9.8711^{* * * *}$ & $-11.0962^{\text {**** }}$ & 0.5415 & 0.5893 & $0.2048^{* * * *}$ & $0.2050^{\text {***** }}$ & $0.0787^{* * * *}$ & $0.0792^{* * * *}$ \\
\hline & (2.994) & $(3.026)$ & (1.669) & (1.942) & $(0.335)$ & $(0.370)$ & $(0.056)$ & $(0.056)$ & $(0.013)$ & $(0.013)$ \\
\hline
\end{tabular}

Notes: Standard errors are clustered at the firm level for models (1)-(4) and (7)-(10); for models (5) and (6) standard errors are computed by bootstrap. Significance

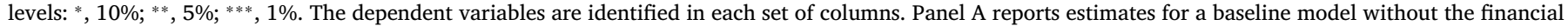

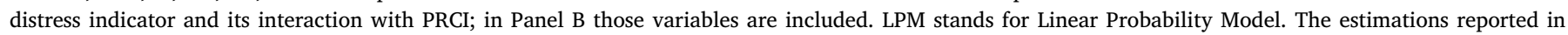
columns (1), (3), (5) and (7) include additionally the following control variables: productivity, part-time workers, fixed-term workers, overtime labor, relative

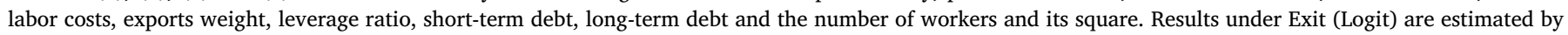

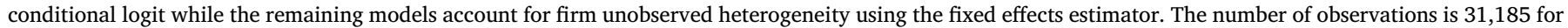

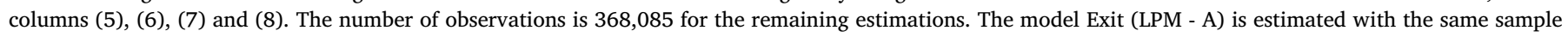
as the model Exit (Logit) model. The model Exit (LPM-B) is estimated with the same sample as the Profit and Employment models.

mated effect on profitability of increasing the minimum wage in 2015 , 2016 and 2017 was $-1.2,-2.3$ and -2.8 p.p., respectively, in the case of non-financially distressed firms, and $-3.8,-7.4$ and -8.8 p.p. in the case of financially distressed firms.

Notice that we are looking at the average effect on profitability associated with the minimum wage increase, rather than to the marginal effect of increasing the minimum wage. There are two reasons for this choice of focus. First, the minimum wage is not an explanatory variable in our models. In our models, the explanatory variable, PRCI, measures the per cent variation in total cost that would occur if, in the current year, the firm adopted the next year's minimum wage (without making any other adjustment). The relation between this variable and the level of the minimum wage depends on the details of the firm's wage and cost structure. Second, given that in the period of our analysis (2013-2017) the Portuguese economy was still recovering from a severe crisis, one might question whether the economy was ready for a minimum wage raise, and what did the raise do to firms' financial condition. In other words, prior to the question of how much it should increase, there was the question of whether it should increase at all, which makes the noincrease case a natural reference point when assessing the impact.

Eq. (2) was also estimated with the per cent change in employment as the dependent variable. The corresponding estimates are in columns (3) and (4) of Table 3 . The estimates are statistically significant at the $1 \%$ significance level, and the estimated $\gamma_{1}$ and $\gamma_{3}$ are negative. Thus, increases in the minimum wage depress employment growth, especially in the case of financially distressed firms. In the case of employment growth, the average effect in 2014, 2015, 2016 and 2017 is, respectively, $-0.2,-0.5,-1.0$, and -1.1 p.p. for non-financially distressed firms, and $-0.7,-2.0,-3.9$ and -4.7 p.p. for financially distressed firms. These results, as well as those for profitability, show that the impact of the minimum wage increases rose over time. This is not unexpected, for one effect of each minimum wage increase has been to augment the concentration of workers on, or close to, the minimum wage level, and these workers are those that will be affected by the next minimum wage increase. In addition, note that $\gamma_{2}$ is now negative: financially distressed firms record lower employment growth than non-financially distressed firms with the same characteristics. This may be part of their strategy to improve performance.

The estimates in columns (5) and (6) of Table 3 - regarding parameters $\beta_{1}, \beta_{2}$ and $\beta_{3}$ of the logit model in Eq. (4) - indicate that an increase in the minimum wage does raise the probability that firms exit $\left(\beta_{1}>0\right)$. As was the case for employment growth and the EBITDA ratio, the magnitude of the impact (in this case, on the argument of the prob- ability of death function) of the minimum wage increase is larger for financially distressed firms $\left(\beta_{3}>0\right)$. However, using robust (bootstrap) standard errors this coefficient is not statistically significant at the $10 \%$ significance level.

Assume that the firm has a zero fixed effect $\left(\eta_{i}=0\right)$ and ignore controls (as remarked above, the estimates do not change much). Under these conditions, for non-financially distressed firms $\left(F D F_{i, t}=0\right)$, the impact of a minimum wage increase on a firm's probability of exit is given by the difference between the probability of exit when there is a fraction of workers affected by the future minimum wage increase $\left(P R C I_{i t}>0\right)$ and the probability of death when there is no minimum wage increase in the following year $\left(P R C I_{i t}=0\right)$. Mathematically, this difference is given by

$\Delta_{\text {non }}\left(P R C I_{i t}\right)=\lambda\left(\beta_{1} P R C I_{i t}\right)-\lambda(0)$

For financially distressed firms $\left(F D F_{i, t}=1\right)$, the impact of a minimum wage increase is

$\Delta_{\text {full }}\left(P R C I_{i t}\right)=\lambda\left[\left(\beta_{1}+\beta_{3}\right) P R C I_{i t}+\beta_{2}\right]-\lambda\left(\beta_{2}\right)$

If we continue to take the logit model literally, the impact of the minimum wage increase may be represented by the diagram in Fig. 3 . In terms of Fig. $3, \lambda(0)$ corresponds to 'non-FDF \& no Treatment', $\lambda\left(\beta_{1} P R C I_{i t}\right)$ to 'non-FDF \& Treatment', $\lambda\left(\beta_{2}\right)$ to 'FDF \& no Treatment', and $\lambda\left[\left(\beta_{1}+\beta_{3}\right) P R C I_{i t}+\beta_{2}\right]$ to 'FDF \& (full) Treatment'. In Fig. 3 there is another curve, 'FDF \& (simple) Treatment', which represents the function $\lambda\left(\beta_{1} P R C I_{i t}+\beta_{2}\right)$. This is the effect on a hypothetical financially distressed firm in the case when increases in the minimum wage impact both financially and non- financially distressed firms in the same way, i.e. when $\beta_{3}=0$. For this hypothetical firm, the effect is

$\Delta_{\text {simple }}\left(P R C I_{i t}\right)=\lambda\left(\beta_{1} P R C I_{i t}+\beta_{2}\right)-\lambda\left(\beta_{2}\right)$

Note that in Fig. 3 the variable on the horizontal axis is the treatment variable $(P R C I)$. Thus, the vertical difference between the 'non-FDF \& Treatment' and the 'non-FDF \& no Treatment' curves gives $\Delta_{n o n}(P R C I)$; $\Delta_{f u l l}(P R C I)$ is the vertical difference between the 'FDF \& (full) Treatment' and the 'FDF \& no Treatment' curves; and $\Delta_{\text {simple }}(P R C I)$ is the vertical difference between the 'FDF \& (simple) Treatment' and the 'FDF $\&$ no Treatment' curves. The vertical lines in Fig. 3 identify the average $P R C I_{i t}$ for financially distressed firms in each year in our sample (2013-2016), i.e., they correspond to 'PRCI (FDF)' in Fig. 2. The average treatment for non-financially distressed firms in 2013 and 2014 is similar to that of financially distressed firms, in 2015 is 0.25 and in 2017 is 0.29 , which is the average for financially distressed firms in 2015 . 


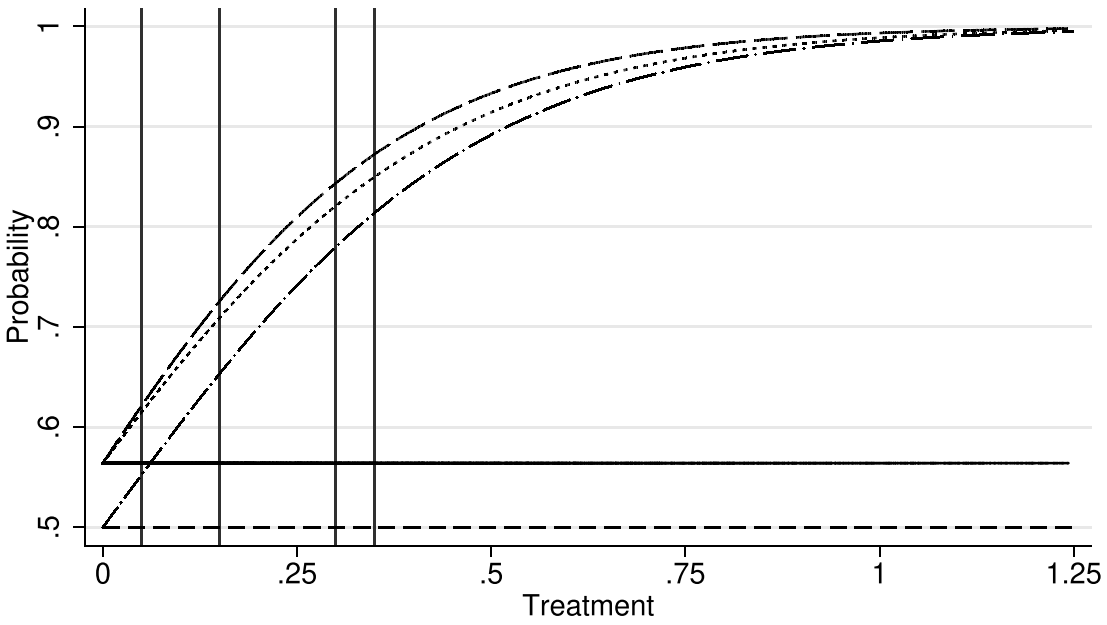

$$
\begin{array}{ll}
- \text { FDF \& no Treatment } & ----- \text { non-FDF \& no Treatment } \\
\cdots \ldots . . . . & \text { FDF \& (simple) Treatment } \\
- & -
\end{array}
$$

Table 4

Impact on the probability of exit (\%) of the average firm.

\begin{tabular}{lcccc}
\hline & 2013 & 2014 & 2015 & 2016 \\
\hline Logit & & & & \\
Non-FDF & 5.0 & 13.4 & 24.5 & 27.5 \\
FDF & 5.6 & 15.9 & 27.3 & 30.4 \\
LPM A (firms that exited) & & & & \\
Non-FDF & 2.6 & 7.2 & 14.0 & 16.2 \\
FDF & 3.7 & 11.1 & 21.9 & 25.9 \\
LPM B (all firms) & & & & \\
Non-FDF & 0.2 & 0.5 & 1.0 & 1.2 \\
FDF & 0.6 & 1.7 & 3.4 & 4.1 \\
\hline
\end{tabular}

Notes: The numbers are the difference in the probability of exit between a firm with a value for the treatment variable equal to the average of that variable for the same category of firms (non-FDF or FDF) in each year, and a firm with the same characteristics but a zero value for the treatment variable. "Logit" uses the estimates in column (5) of Table 3. "LPM - A" and "LPM - B" use the estimates in columns (7) and (9), respectively.

Consequently, to avoid cluttering the plot, we did not draw additional lines to represent the average values for non-financially distressed firms in Fig. 3.

Thus, on average, the minimum wage increase in 2014 (treatment in 2013) led to the probability of exit rising five percentage points see Table 4 . The estimated average impact rises over time to about 30 percentage points in 2017. The variations for financially distressed firms are a bit higher than for non-financially distressed firms, namely in later years. It is also visible in Fig. 3 that the additional impact on financially distressed firms $\left(\beta_{3}>0\right)$ led to the probability of exit rising by a relatively low amount; unsurprising given that $\beta_{3}$ is not statistically significant. This additional effect is about half of a percentage point in 2014, one percentage point in 2015, two in 2016 and three in 2017. Obviously, these results are conditional on the fixed effect equaling zero; on other points of the curve, the impacts will be different. These results are also conditional on the logit functional form.

As an alternative to the logit functional form, in columns (7) and (8) of Table 3 we report the estimates obtained using the linear probability model, estimated in the same sample as the logit model, i.e., the sample of firms that did exit during 2014-2017. The coefficients are all positive and statistically significant at the $1 \%$ significance level. Hence, qualitatively the results are the same as in the logit model, with the added significance of the interaction term. Quantitatively, the change
Fig. 3. Minimum wage PRCI treatment effects Source: Authors' computations using data from SCIE and QP. in the probability of exit assigned to the minimum wage rise is a bit lower than in the logit model - see the mid-section of Table 4. This is especially so for non-financially distressed firms, for which this model estimates impacts that are not much higher than half of the logit estimates. Nevertheless, the magnitude of the average impact is still reasonably large, reaching 16 p.p. in 2016 . For financially distressed firms, the linear model also produces lower estimates of the average impact than the logit model, but the difference is relatively small (less than 6 p.p.). In short, the linear probability model attenuates the magnitude of the average impact of the minimum wage increases, but is in line with the conclusions derived from the logit model.

We also estimated the linear probability model on the full sample of firms. The results are in columns (9) and (10) of Table 3. Extending the sample to include the firms that did not exit during 2014-2017 makes some difference. First, the dummy for financially distressed firms is no longer statistically significant. Second, and more importantly, the attenuation effect detected above is now much stronger - see the lower section of Table 4. The estimated average impact is now in the range $0.2-1.2$ for non-financially distressed firms, and in the range $0.6-4.1$ for financially distressed firms. Nevertheless, the conclusion that the minimum wage rises increased the probability of death still holds.

The positive impact of minimum wage increases on the probability of exit contributed to accelerate the insolvency of less productive firms. In Table 5, we report productivity and profitability statistics, by class of firms and year, for firms that survived and for firms that exited the market. The statistics for productivity show that the firms that exited the market tended to be much less productive than the firms that survived. Therefore, our results suggest that minimum wage policies might have produced a cleansing effect, as in Mayneris et al. (2018), contributing to improve aggregate productivity.

As a robustness check we estimated the models in Table 3 adding interactions between $F D F$ and the control variables. The estimates of these robustness checks corroborate the conclusions of the paper. The main results of the paper are also robust to different definitions of financially distressed firms, namely the ones discussed in Section 2. In other words, the results are not dependent on a specific, narrower definition of financial distress. As another robustness check, we estimated Eq. (2) omitting the observations for firms that exited in $t+1$. Our main conclusions are not affected: PRCI has a statistically significant negative impact on profitability, although the interaction with $F D F$ is not statistically significant in this version. The estimates corroborate the conclusion that $P R C I$ and $F D F$ have a negative impact on employment 
Table 5

Productivity and profitability by exit and financial status.

\begin{tabular}{|c|c|c|c|c|c|c|c|c|c|}
\hline \multicolumn{2}{|l|}{ Year } & \multirow{2}{*}{$\frac{2013}{\text { Mean }}$} & \multicolumn{3}{|c|}{2014} & \multicolumn{2}{|l|}{2015} & \multicolumn{2}{|l|}{2016} \\
\hline \multicolumn{9}{|c|}{$\begin{array}{l}\text { Median Mean } \\
\text { Productivity (Euro per hour) }\end{array}$} & \\
\hline \multirow{4}{*}{ Non-Exited } & All & 16.16 & 10.80 & 16.33 & 11.10 & 20.77 & 11.71 & 17.92 & 12.15 \\
\hline & Non-FDF & 16.74 & 11.13 & 17.02 & 11.47 & 21.50 & 12.03 & 18.36 & 12.39 \\
\hline & FDF & 5.57 & 4.74 & 4.19 & 4.67 & 4.47 & 4.83 & 5.51 & 5.14 \\
\hline & All & 9.21 & 6.48 & 9.89 & 6.68 & 12.67 & 7.56 & 12.91 & 8.86 \\
\hline \multirow[t]{2}{*}{ Exited } & NonFDF & 12.83 & 7.38 & 12.34 & 7.51 & 14.22 & 8.32 & 14.41 & 9.58 \\
\hline & FDF & -11.18 & 2.97 & -3.59 & 2.59 & 2.04 & 2.51 & -0.74 & 2.93 \\
\hline \multicolumn{10}{|c|}{ Profitability (\%) } \\
\hline \multirow{3}{*}{ Non-Exited } & All & 1.91 & 4.97 & 2.76 & 5.50 & 4.98 & 6.14 & 6.14 & 6.51 \\
\hline & Non-FDF & 3.66 & 5.42 & 4.56 & 6.01 & 6.38 & 6.56 & 7.23 & 6.86 \\
\hline & FDF & -29.87 & -16.65 & -28.98 & -14.95 & -26.29 & -13.77 & -24.58 & -13.08 \\
\hline \multirow{3}{*}{ Exited } & All & -22.76 & -6.71 & -22.09 & -4.85 & -14.70 & -0.41 & -8.37 & 2.37 \\
\hline & NonFDF & -18.15 & -1.59 & -17.04 & -0.02 & -9.86 & 1.69 & -4.72 & 3.62 \\
\hline & FDF & -48.71 & -31.86 & -49.78 & -29.45 & -47.69 & -30.96 & -41.48 & -27.82 \\
\hline
\end{tabular}

Source: QP \& SCIE. The number of observations for the year 2013, 2014, 2015 and 2016 is, respectively, 99790, 94146, 89,145 and 85004.

and that $F D F$ amplifies the effect of PRCI. Finally, note that, to preempt endogeneity issues, all explanatory variables are lagged relative to the dependent variables: the dependent variables represent changes from $t$ to $t+1$, while the explanatory variables concern period $t$. Nevertheless, we also estimated the models with $F D F$ lagged one period, which did not change our conclusions.

\section{Conclusion}

In this paper, we evaluated the impact of significant and consecutive minimum wage increases in the Portuguese economy since 2014. Our estimates suggest that minimum wage policies had a negative impact on profitability and employment. Additionally, the results indicate that the impact was magnified for financially distressed firms. The financial vulnerability of those firms also lowered their ability to survive following the increase in wage costs.

These results contribute to a better understanding of the impact of minimum wage policies on firms. So far, most studies of the impact of minimum wage policies have been focused on employment and other dimensions of labor markets. This paper presents evidence that minimum wage policies affect the financial situation of firms and their survival. Therefore, these are issues that policymakers should bear in mind when setting new floors for wages.

The assessment of minimum wage policies in Portugal, since 2014, carried out in this paper suggests that the negative impact on employment and profitability may have been compensated for the economy as a whole by the expansionary phase of the business cycle. On the other hand, our results also suggest that minimum wage policies might have had a supply side effect. The exit of lower productivity firms caused by the increase in wage costs might have worked as a cleansing effect, contributing to higher aggregate productivity.

The impact of the COVID-19 pandemic crisis and Governments' intervention to support firms revived the issue of zombie firms. The ECB's 2021 Financial Stability Review calls the attention to the risks of inefficient insolvency frameworks, which might contribute to an increasing share of zombie firms in the economy. Our results suggest that minimum wage increases might work similarly to the "high-pressure economy" zombie firms selection mechanism advocated by Gagnon (2021): in a "high-pressure economy", only non-zombie firms will be able to pay the wages required to retain and attract workers.

Therefore, the channels through which productivity may benefit from minimum wage policies deserve further investigation, namely by analyzing the reallocation of resources from the firms that exit the market to new or incumbent firms.

\section{References}

Aaronson, D., French, E., Sorkin, I., To, T., 2018. Industry dynamics and the minimum wage: a putty-clay approach. Int. Econ. Rev. 59 (1), 51-84.

Alexandre, F., Aguiar-Conraria, L., Bação, P., 2019. Crise e castigo e o dia seguinte. Fundação Francisco Manuel dos Santos, Lisboa.

Bell, B., Machin, S., 2018. Minimum wages and firm value. J. Labor Econ. 36 (1), 159-195.

Blanchard, O., Portugal, P., 2017. Boom, slump, sudden stops, recovery, and policy options. Portugal and the Euro. Port. Econ. J. 16 (3), 149-168.

Caballero, R.J., Hoshi, T., Kashyap, A.K., 2008. Zombie lending and depressed restructuring in Japan. Am. Econ. Rev. 98 (5), 1943-1977.

Caliendo, M., Fedorets, A., Preuss, M., Schröder, C., Wittbrodt, L., 2018. The short-run employment effects of the German minimum wage reform. Labour Econ. 53, 46-62.

Card, D., Krueger, A., 1994. Minimum wages and employment: a case study of the fast-food industry in New Jersey and Pennsylvania. Am. Econ. Rev, 84 (4), 772-793.

Centeno, M., Duarte, C., Novo, Á. A., 2014. The impact of the minimum wage on match stability. IZA Discussion Paper No. 8703.

Chava, S., Oettl, A., Singh, M., 2019. Does a one-size-fits-all minimum wage cause financial stress for small businesses?NBER Working Paper No. 26523.

Draca, M., Machin, S., Van Reenen, J., 2011. Minimum wages and firm profitability. Am. Econ. J. Appl. Econ. 3 (1), 129-151.

Drucker, L., Mazirov, K., Neumark, D., 2021. Who pays for and who benefits from minimum wage increases? Evidence from Israeli tax data on business owners and workers. J. Public Econ.. forthcoming

Dube, A., 2019. Impacts of Minimum Wages: Review of the International Evidence. HM Treasury, London. Available at: https://assets.publishing.service.gov.uk/ government/uploads/system/uploads/attachment_data/file/844350/impacts_of_ minimum wages review of the international evidence Arindrajit Dube web.pdf

European Banking Authority, 2020. First Evidence on the Use of Moratoria and public Guarantees in the EU Banking Sector. European Banking Authority Thematic. Note EBA/Rep/2020/31. Available at: https://www.eba.europa.eu/sites/ default/documents/files/document library/Risk\%20Analysis

European Central Bank, 2021. Financial stability review. Third Issue, May. Available at: https://www.ecb.europa.eu/pub/financial-stability/fsr/html/ecb.fsr202105 757f727fe4.en.html.

Gagnon, J. E., 2021. Zombies are a symptom of economic weakness, not a cause. Peterson Institute for International Economics, https://www.piie.com/commentary/ op-eds/zombies-are-symptom-economic-weakness-not-cause, [2021-05-17].

Gouveia, A. F., Osterhold, C., et al., 2018. Fear the walking dead: zombie firms, spillovers and exit barriers. OECD Productivity Working Papers No. 13.

Harasztosi, P., Lindner, A., 2019. Who pays for the minimum wage? Am. Econ. Rev. 109 (8), 2693-2727.

INE-Statistics Portugal, 2018a. Quadros de Pessoal. Instituto Nacional de Estatística, Lisboa.

INE-Statistics Portugal, 2018b. Sistema de Contas Integradas das Empresas. Instituto Nacional de Estatística, Lisboa.

Luca, D. L., Luca, M., 2019. Survival of the fittest: the impact of the minimum wage on firm exit. NBER Working Paper No. 25806.

Machin, S., Manning, A., Rahman, L., 2003. Where the minimum wage bites hard: introduction of minimum wages to a low wage sector. J. Eur. Econ. Assoc. 1 (1), 154-180. doi:10.1162/154247603322256792.

Mayneris, F., Poncet, S., Zhang, T., 2018. Improving or disappearing: firm-level adjustments to minimum wages in China. J. Dev. Econ. 135, 20-42.

McGowan, M. A., Andrews, D., Millot, V., 2017. Insolvency regimes, zombie firms and capital reallocation. OECD Economics Department Working Paper No. 1399.

Ministério do Trabalho, Solidariedade e Segurança Social, 2019. Salário mínimo nacional 45 anos depois-Balanço e perspetivas atuais sobre emprego e salários em Portugal. 
Gabinete de Estratégia e Planeamento, Ministério do Trabalho, Solidariedade e Segurança Social..

Neumark, David, Shirley, Peter, 2021. Myth or Measurement: What Does the New Minimum Wage Research Say about Minimum Wages and Job Loss in the United States? NBER Working Paper No. 28388.

Pereira, Sónia C., 2003. The impact of minimum wages on youth employment in Portugal. European Economic Review 47 (2), 229-244. doi:10.1016/S0014-2921(02)00209-X.
Portugal, P., Cardoso, A.R., 2006. Disentangling the minimum wage puzzle: an analysis of worker accessions and separations. J. Eur. Econ. Assoc. 4 (5), 988-1013.

Schivardi, F., Sette, E., Tabellini, G., 2021. Credit misallocation during the European financial crisis. Econ. J.. forthcoming

Storz, M., Koetter, M., Setzer, R., Westphal, A., 2017. Do we want these two to tango? On zombie firms and stressed banks in Europe. ECB Working Paper No. 2104. 